\title{
ERRATA
}

\section{Minimal Water Activity for Enterotoxin A Production and Growth of Staphylococcus aureus}

\author{
L. P. LOTTER AND L. LEISTNER*
}

Institute of Bacteriology and Histology, Federal Center for Meat Research, 8650 Kulmbach, Federal Republic of Germany

Volume 36, number 2, pages 378 and 379, Tables 2 and 3: The amounts of enterotoxin A (micrograms per milliliter) at $a_{w} 0.890$ and below should be divided by 40 because toxin material was concentrated 40 -fold, excluding the control broth without added salts.

\section{Improved Methods for Detecting Enteric Viruses in Oysters}

MARK D. SOBSEY,* ROBERT J. CARRICK, AND HAROLD R. JENSEN

Department of Environmental Sciences and Engineering, School of Public Health, University of North Carolina, Chapel Hill, North Carolina 27514

Volume 36, number 1, page 127, Figure 1: The concentration of $\mathrm{Na}_{2} \mathrm{HPO}_{4}$ should read " $0.1 \mathrm{M}$." 